\title{
Assessment of the shovel-truck system operation quality at open-pit mines in Kuzbass
}

\author{
Anton Voronov ${ }^{1}$, Alexey Khoreshok ${ }^{2}$, Yuri Voronov $^{2 *}$, and Artyom Voronov ${ }^{2}$ \\ ${ }^{1}$ Kuzbassrazrezugol Coal Company JSC, Kemerovo, Russian Federation \\ ${ }^{2}$ T.F. Gorbachev Kuzbass State Technical University, Kemerovo, Russian Federation
}

\begin{abstract}
Assessment of the shovel-truck system (STS) operation quality is based on the well-known method of non-expert assessment of the quality of mining machines. The methodology is based on the fundamental principles of qualimetry and allows making the assessment of functionally homogeneous machines of different sizes, types and designs based on the functional criterion of the machine, which determines its main purpose. In this work, the quality assessment is made not for a single machine, but for a set of machines, taking into account their interaction. Assessment of the STS operation quality allows us to create a basis for the selection of priority areas for its improvement. The work uses methods of mathematical modeling, data collection and processing, statistics, analysis and synthesis. A comprehensive quality assessment makes it possible to predict the level and select priority areas for improving existing STSs or STSs being projected.
\end{abstract}

\section{Introduction}

With regard to the mechanical equipment of open-pit mines (drilling rigs, single-bucket excavators, mining haul trucks), this technique was used in [1-5]. Differences in the methodology options in these works are in functional criteria specific to each machine and in the set of quality indicators. Interpretation of the methodology for shovel-truck systems has not yet been made.

Comprehensive quality assessment includes the following stages [6]: selection of a functional quality assessment criterion; justification and definition of quality indicators; quality assessment of existing STSs at open-pit mines in Kuzbass; analysis of the results of the STS quality assessment and the choice of promising directions for the quality improvement.

\section{Functional criterion selection}

Assessment of the STS operation quality at existing open-pit mines, which are parts of the Kuzbassrazrezugol Coal Company JSC (KRU), is carried out under the following condi-

\footnotetext{
*Corresponding author: vyue.ap@kuzstu.ru
} 
tions. The study is based on summary reports on the STS operation at six open-pit coal mines and, in general, for the KRU, including the actual data obtained at the mining operation. These reports are presented in Table 1.

Table 1. Report on the STS operation at separate mines and the Kuzbassrazrezugol Company

\begin{tabular}{|c|c|c|c|c|c|c|c|}
\hline \multirow[b]{2}{*}{ Indicators } & \multicolumn{6}{|c|}{ Mines } & \multirow[b]{2}{*}{ 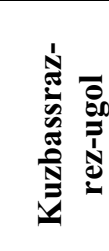 } \\
\hline & $\begin{array}{l}\frac{\lambda}{0} \\
0 \\
0 \\
0 \\
0 \\
0 \\
0 \\
0 \\
0\end{array}$ & $\begin{array}{l}\frac{3}{2} \\
\frac{0}{0} \\
\frac{0}{0} \\
\frac{1}{0}\end{array}$ & 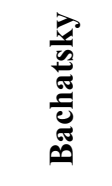 & 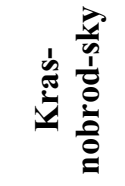 & $\frac{\vec{\lambda}}{\frac{\pi}{\tilde{n}}}$ & 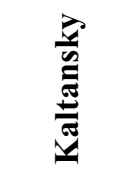 & \\
\hline $\begin{array}{l}\text { Number of shov- } \\
\text { el fleet, } \\
N_{S} \text {, units }\end{array}$ & 8 & 10 & 9 & 12 & 14 & 10 & 63 \\
\hline $\begin{array}{l}\text { Number of truck } \\
\text { fleet, } \\
N_{t} \text {, units }\end{array}$ & 31 & 28 & 67 & 93 & 91 & 31 & 341 \\
\hline $\begin{array}{l}\text { Number of per- } \\
\text { formed hauls, } n_{r}\end{array}$ & 1064 & 1632 & 1833 & 3518 & 3372 & 1241 & 12660 \\
\hline $\begin{array}{l}\text { Total in-shift } \\
\text { downtime of } \\
\text { equipment, } \\
t_{d}^{E}, \text { min. }\end{array}$ & 4812 & 4874 & 7114 & 4209 & 6376 & 1741 & 29135 \\
\hline $\begin{array}{l}\text { Truck downtime, } \\
t_{d}^{t}, \text { min. }\end{array}$ & 2126 & 1022 & 5620 & 1947 & 2818 & 457 & 13991 \\
\hline $\begin{array}{l}\text { Shovel down- } \\
\text { time, } \\
t_{d}^{s}, \text { min. }\end{array}$ & 2694 & 3852 & 1494 & 2262 & 3558 & 1471 & 15331 \\
\hline $\begin{array}{l}\text { Loading time, } \\
t_{l}^{S}, \text { min. }\end{array}$ & 4004 & 6041 & 4528 & 9567 & 9750 & 4448 & 38337 \\
\hline $\begin{array}{l}\text { Truck mileage } \\
\text { per day, } \\
L, \mathrm{~km}\end{array}$ & 3714 & 3361 & 10611 & 16182 & 13072 & 4722 & 51661 \\
\hline $\begin{array}{l}\text { Loaded travel } \\
\text { time, } \\
t_{l t}, \min .\end{array}$ & 13505 & 11639 & 36687 & 55997 & 45022 & 16282 & 179131 \\
\hline $\begin{array}{l}\text { Empty travel } \\
\text { time, } \\
t_{e t}, \min .\end{array}$ & 10013 & 9395 & 27965 & 42573 & 34307 & 12500 & 136752 \\
\hline $\begin{array}{l}\text { Haul time, } \\
t_{h}, \text { min. }\end{array}$ & 29257 & 28960 & 73142 & 112348 & 95126 & 34908 & 373741 \\
\hline $\begin{array}{l}\text { Haul time with } \\
\text { downtime, } \\
\left(t_{h}+t_{d}^{T}\right), \text { min. }\end{array}$ & 34076 & 33835 & 80256 & 116557 & 101502 & 36649 & 402876 \\
\hline $\begin{array}{l}\text { Equipment oper- } \\
\text { ation time, } \\
T_{s h}, \mathrm{hr} .\end{array}$ & 18,32 & 20,14 & 19,96 & 20,89 & 18,59 & 19,70 & 19,69 \\
\hline
\end{tabular}

Note. The table shows weighted average values of the corresponding indicators for operations. 
The functional criterion for assessing the STS operation quality is the ratio of the rate of truck arrive for loading and the rate of truck service by shovels, justified and defined in [7, 8]. The results of calculating the functional criterion are summarized in Table 2.

Table 2. The results of calculating the functional criterion for assessing the STS operation quality at open-pit coal mines

\begin{tabular}{|c|c|c|c|c|c|c|}
\hline \multirow[b]{2}{*}{ Indicators } & \multicolumn{6}{|c|}{ Mines } \\
\hline & 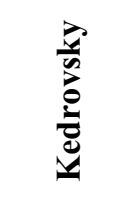 & $\begin{array}{l}\frac{\lambda}{n} \\
\frac{1}{2} \\
\frac{1}{2} \\
\frac{1}{0} \\
\sum\end{array}$ & 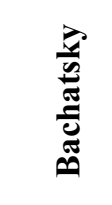 & 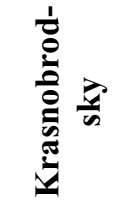 & 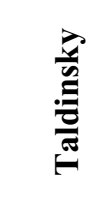 & 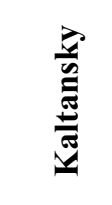 \\
\hline \multicolumn{7}{|c|}{ Initial data } \\
\hline$N_{t}$, units & 31 & 28 & 67 & 93 & 91 & 3 \\
\hline$N_{s}$, units & 8 & 10 & 9 & 12 & 14 & 10 \\
\hline$\frac{N_{S}}{t_{l}^{s}}, \min ^{-1}$ & 2,126 & 2,701 & 3,644 & 4,413 & 4,843 & 2,790 \\
\hline$t_{h}, \min$ & 27,497 & 17,746 & 39,903 & 31,934 & 28,211 & 28,128 \\
\hline$\Sigma_{1}^{S} t_{d}^{S}, \min$ & 2694,0 & 3852,0 & 1494,0 & 2262,0 & 3558,0 & 1470,6 \\
\hline$\Sigma_{1}^{t} t_{d}^{t}, \min$ & 2125,8 & 1022,4 & 5620,2 & 1947,0 & 2818,2 & 457,2 \\
\hline$T_{s h}, \min$ & 1099,2 & 1208,4 & 1197,9 & 1253,3 & 1115,4 & 1182,2 \\
\hline \multicolumn{7}{|c|}{ Calculation results } \\
\hline$t_{l}^{S}, \min$ & 3,763 & 3,702 & 2,470 & 2,719 & 2,891 & 3,584 \\
\hline$k_{S T S}$ & 0,888 & 0,894 & 0,922 & 0,968 & 0,946 & 0,964 \\
\hline$\lambda$ & 0,597 & 0,653 & 0,500 & 0,682 & 0,704 & 0,410 \\
\hline
\end{tabular}

\section{Justification and definition of quality indicators}

In [9] it was established that the main indicators characterizing the STS operation quality are: performance indicators of the STS shovel and truck fleets ( $P^{S}$ and $P^{t}$ respectively), $\mathrm{m}^{3} / \mathrm{min}$; ; operating speed of trucks as part of the STS $\left(\vartheta_{t}\right), \mathrm{kph}$; the share of equipment downtime in the shift duration $\left(k_{d}^{\Sigma}\right)$; ratio of shovel and truck downtimes $\left(k_{d}^{s-t}\right)$; the level of productive use of the STS shovel and truck fleets ( $k_{u}^{s}$ and $k_{u}^{t}$ respectively). Dependences for its determination are also given there. The results of calculating the STS performance indicators are summarized in Table 3.

Further, according to the method, for the data in Tables 2 and 3, single $\left(q_{m n}\right)$ and generalized $\left(k_{m}\right)$ indicators of the STS operation quality are calculated using the corresponding formulas of the method. The calculation results are presented in Table 4. At the same time, mines are ranked in the table according to the generalized indicator of the STS operation quality.

General analysis of the generalized indicator of the STS operation quality level at KRU mines (Table 4) shows that at three out of six mines it is higher than 0,5 , and at two it is approaching this value. This testifies to the general sufficient quality of the STS operation at mines. Only one mine, Kaltansky, is noticeably behind. The reason is the low level of the shovel fleet productivity $\left(P^{s}=29,2 \mathrm{~m}^{3} / \mathrm{min}\right.$.; Table 3$)$. This requires a small number of 
trucks serving shovels, as a result of which the value $k_{N}^{\prime}=N_{t} / N_{s}$ (where $N_{s}, N_{t}$ is the number of shovels and trucks in the STS, respectively) is only 3,10 , and it directly determines the functional criterion $\lambda$. And it has the smallest value in the STS of the Kaltansky mine $(\lambda=0,410)$

Table 3. Initial calculated STS performance indicators

\begin{tabular}{|c|c|c|c|c|c|c|}
\hline \multirow[b]{2}{*}{ Indicators } & \multicolumn{6}{|c|}{ Mines } \\
\hline & 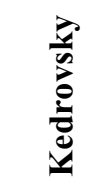 & 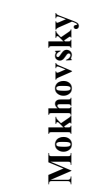 & 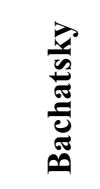 & 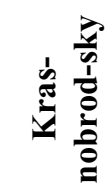 & 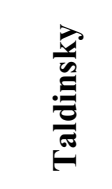 & 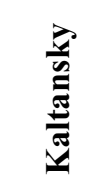 \\
\hline $\begin{array}{l}\text { Shovel fleet performance indi- } \\
\text { cator, } P^{s}, \mathrm{~m}^{3} / \mathrm{min} \text {. }\end{array}$ & 40,32 & 21,14 & 64,19 & 45,24 & 50,18 & 29,20 \\
\hline $\begin{array}{l}\text { Truck fleet performance indica- } \\
\text { tor, } P^{t}, \mathrm{~m}^{3} / \mathrm{min} \text {. }\end{array}$ & 4,518 & 4,022 & 3,574 & 3,515 & 4,142 & 3,996 \\
\hline $\begin{array}{l}\text { Operating speed of trucks, } \vartheta_{t} \text {, } \\
\text { kph }\end{array}$ & 13,08 & 11,92 & 15,87 & 16,66 & 15,47 & 15,44 \\
\hline $\begin{array}{l}\text { Share of equipment downtime } \\
\text { in the shift duration, } k_{d}^{\Sigma}\end{array}$ & 0,167 & 0,155 & 0,117 & 0,0476 & 0,0952 & 0,064 \\
\hline $\begin{array}{l}\text { Ratio of shovel and truck down- } \\
\text { times, } k_{d}^{s-t}\end{array}$ & 0,902 & 2,796 & 0,189 & 0,690 & 0,583 & 1,409 \\
\hline $\begin{array}{l}\text { Level of productive use of the } \\
\text { shovel fleet, } k_{u}^{s}\end{array}$ & 1,486 & 1,569 & 3,031 & 4,229 & 2,740 & 3,024 \\
\hline $\begin{array}{l}\text { Level of productive use of the } \\
\text { truck fleet, } k_{u}^{t}\end{array}$ & 9,508 & 20,77 & 8,980 & 33,86 & 15,04 & 32,88 \\
\hline
\end{tabular}

Table 4. Single and generalized indicators of the STS operation quality

\begin{tabular}{|c|c|c|c|c|c|c|c|}
\hline \multirow{2}{*}{\multicolumn{2}{|c|}{ Indicators }} & \multicolumn{6}{|c|}{ Mines } \\
\hline & & \multirow{2}{*}{ 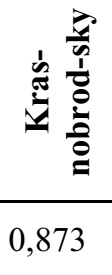 } & \multirow{2}{*}{ 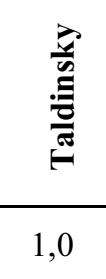 } & \multirow{2}{*}{ 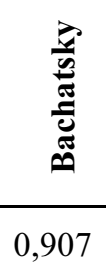 } & \multirow{2}{*}{ 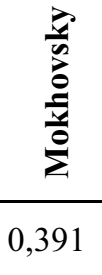 } & \multirow{2}{*}{ 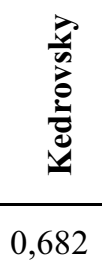 } & \multirow{2}{*}{ 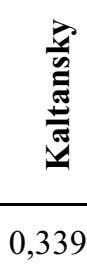 } \\
\hline \multirow{7}{*}{ 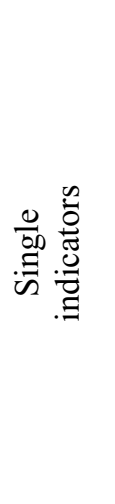 } & $q_{1}\left(P^{S}\right)$ & & & & & & \\
\hline & $q_{2}\left(P^{t}\right)$ & 0,823 & 1,0 & 0,613 & 0,900 & 0,925 & 0,562 \\
\hline & $q_{3}\left(\vartheta_{t}\right)$ & 1,0 & 0,959 & 0,698 & 0,685 & 0,687 & 0,557 \\
\hline & $q_{4}\left(k_{d}^{\Sigma}\right)$ & 1,0 & 0,519 & 0,299 & 0,295 & 0,250 & 0,452 \\
\hline & $q_{5}\left(k_{d}^{s-t}\right)$ & 0,374 & 0,457 & 1,0 & 0,088 & 0,250 & 0,110 \\
\hline & $q_{6}\left(k_{u}^{s}\right)$ & 1,0 & 0,670 & 0,526 & 0,356 & 0,308 & 0,430 \\
\hline & $q_{7}\left(k_{u}^{t}\right)$ & 1,0 & 0,459 & 0,194 & 0,588 & 0,246 & 0,584 \\
\hline neralized & $k_{m}$ & 0,879 & 0,737 & 0,626 & 0,494 & 0,499 & 0,446 \\
\hline
\end{tabular}


indicators

The STS operation quality level (for the whole KRU Company) is $k^{K R U}=0,614$. Therefore, further analysis will be made in comparison with this value. Comparison of the generalized indicator of the STS operation quality at mines with the general indicator for the KRU shows that it is above the average value at three mines (Krasnobrodsky, Taldinsky and Bachatsky), and it is below the average at three mines (Mokhovsky, Kedrovsky and Kaltansky) too. The reason for the high quality level at first three mines and low at the latter three is the same as in the previous case.

Krasnobrodsky mine is the standard for four out of seven single quality indicators (operating speed of trucks $\vartheta_{t}$, the share of downtime in the shift duration $k_{d}^{\Sigma}$, indicators of the productive use of shovel $k_{u}^{s}$ and truck $k_{u}^{t}$ fleets), as a result of which it occupies the 1st place in the ranked list $(k=0,879)$. Taldinsky mine is the first in two single indicators (performance indicators of shovel $P^{s}$ and truck $P^{t}$ fleets) and takes the 2nd place with a value of $k=0,737$. And the Top- 3 is completed by the Bachatsky mine, which is the best in one single indicator reflecting the ratio of shovel and truck downtimes $k_{d}^{s-t}$. This mine could have much better performance, but the haul distance is too long $\left(L_{h}=5,79 \mathrm{~km}\right)$, which means that the haul time $t_{h}$ and the functional criterion $\lambda$ negate its advantages in other significant indicators.

\section{Selecting directions for improving the STS operation quality}

To determine the main directions for improving the STS operation quality, we also use the data in Table 4.

Analysis of the single indicator $q_{1}\left(P^{s}\right)$, which characterizes the capabilities of the STS shovel fleet in terms of loading the required volume of material, shows that Krasnobrodsky, Taldinsky and Bachatsky mines have very high values of this indicator (for them, the weighted average of its value is 0,927$)$. The overall quality level for this indicator for the whole KRU is 0,699 , which is $28,0 \%$ lower than in the leading group. In the group lagging behind in this indicator, there are also three mines: Mokhovsky, Kaltansky and, to a lesser extent, Kedrovsky. The weighted average value of the indicator for them is 0,471 , which is $39,0 \%$ lower than for the whole KRU. Thus, the group of outsider mines has a 1,4 times greater influence on the value of this indicator for the whole KRU than leading mines.

The second indicator for which there is a clear group of leaders is the single indicator $q_{2}\left(P^{t}\right)$, which reflects the capabilities of mining truck fleets. These are Krasnobrodsky, Taldinsky, Mokhovsky and Kedrovsky mines. The general level of the STS operation quality for this indicator is 0,912 ; for the whole KRU it is 0,804 (excess $-12,6 \%$ ). The group of outsiders includes Bachatsky and Kaltansky mines. For them, the overall quality level for this indicator is 0,588 , which is $31,0 \%$ lower than the average for the KRU. This is one of two single indicators, for which, even in the group of outsider mines, the average quality level is above 0,5 . This means that the capabilities of truck fleets at all mines are sufficient to ensure the timely removal of required volumes of material. At the same time, for the Bachatsky mine, for example, good capabilities of the shovel fleet are combined with rather low capabilities of the truck fleet. Such a discrepancy between the equipment fleet capabilities at this mine leads to a noticeable decrease in the value of the generalized indicator, as a result of which the mine is only at the 3 rd place in the ranked list.

Analysis of the single indicator $q_{3}\left(\vartheta_{t}\right)$, reflecting the effectiveness of the truck operating speed influence on the level of the STS operation quality, indicates, first of all, that only two mines (Krasnobrodsky and Taldinsky) out of six have significantly higher values of this indicator than the rest. The overall STS quality level for this indicator at these mines is 
0,980 , which is $24,8 \%$ higher than for the whole $\mathrm{KRU}(0,764)$. This indicator, like the previous one, has a quality level of 0,659 even for lagging mines, which is higher than 0,5 . This confirms the conclusion drawn from the previous indicator: the possibilities of truck fleets at all mines are great, and if the mine is not high in the ranked list in terms of the generalized quality indicator, then the reason for this is the weak results of its operation in other indicators.

The situation is much worse with the indicator $q_{4}\left(k_{d}^{\Sigma}\right)$, which characterizes the impact of the total downtime of load \& haul equipment on the STS operation quality. Only two mines (Krasnobrodsky and Taldinsky) have the indicator higher than 0,5 and than for the whole KRU $(0,469)$, and for the whole KRU, the indicator is below 0,5 . This indicates a problem with equipment downtime at most mines - it is too large. The weighted average value of the indicator in the leading group is 0,760 (excess of $47,5 \%$ compared to the average for the KRU); in the group of outsider mines - only 0,324 , which is $36,6 \%$ lower than for the whole KRU.

The situation is similar with the indicator $q_{5}\left(k_{d}^{s-t}\right)$, which characterizes the ratio of shovel and truck downtimes and shows the effectiveness of its influence on the STS operation quality. It should be noted that this influence is negative. Downtime for expensive shovels is too large compared to the downtime for less expensive trucks. As in the previous case, only two out of six mines (Bachatsky and Taldinsky) have the indicator higher than the average for the KRU, and only at the Bachatsky mine it is above 0,5. The weighted average value of the indicator in the leading group is 0,728 , which is $62,8 \%$ higher than for the whole KRU $(0,380)$. In the group of outsiders, the value of the indicator is 0,206 , which is $59,4 \%$ lower than for the whole KRU. And the situation with this indicator is very bad at the Kaltansky mine and especially at Mokhovsky mine. All this, as in the previous case, testifies to the extreme trouble with the problem of downtime of STS shovel fleets.

From the analysis of the single indicator $q_{6}\left(k_{u}^{s}\right)$, reflecting the efficiency of the ratio of productive (work) and unproductive (downtime) use of shovels, we can see the predominance of two leading mines (Krasnobrodsky and Taldinsky) over the rest mines. The weighted average value of the leader's indicator is 0,835 , which is $41,5 \%$ higher than for the whole KRU $(0,548)$. For outsider mines, this indicator is 0,405 , which is below the boundary value of 0,$5 ; 30,0 \%$ lower than for the whole KRU, and more than 2 times lower than at leading mines. Low values of the indicator at most of the mines indicate large downtime of shovel fleets and the need for its significant reduction.

The situation is somewhat better with the indicator $q_{7}\left(k_{u}^{t}\right)$, which characterizes the rationality of the ratio of operation time and downtime of mining truck fleets. At three mines (Krasnobrodsky, Mokhovsky and Kaltansky), the value of the indicator is higher than for the whole KRU. The weighted average value of the indicator for the leading group is 0,724 , which is $34,3 \%$ higher than for the whole KRU. For three outsider mines, the weighted average value of the indicator is 0,300 , which is $52,2 \%$ lower than for the whole KRU. The situation with this indicator is especially bad at Bachatsky and Kedrovsky mines. STS truck fleets at these mines are idle too much.

The analysis of single indicators of the STS operation quality for the whole KRU indicates a problem with two indicators: $q_{4}\left(k_{d}^{\Sigma}\right)$ and $q_{5}\left(k_{d}^{s-t}\right)$, for which the average values for the KRU are below 0,5. These indicators reflect the share of load \& haul equipment downtime in the shift duration (it is too large), and the ratio of shovel and truck downtime (downtime of shovels, as high-performance and expensive machines, is also too large). It follows that the main efforts should be directed to reducing downtime in general, and especially downtime of shovels.

An assessment of the general state of the STS operation quality at open-pit mines for all indicators and each of indicators can also be made according to Table 4. The situation with the STS operation quality is more or less successful at Krasnobrodsky, Taldinsky and, to a 
lesser extent, Bachatsky mines, for which the weighted average values of the quality level for single indicators are higher than 0,5 . The weighted average value of quality indicators for these mines is 0,732 . The same value for outsider mines is 0,461 , which is $45,4 \%$ lower than that for the leaders.

The general analysis of the results of calculating single indicators shows that the predominant influence on their values is exerted by the functional criterion, which, in turn, as follows from the dependences given in [7,8], is largely determined by the ratio of the number of truck and shovel fleets in the mining STSs. The higher this ratio, the greater the functional criterion value and the higher the value of the corresponding single indicator. Indeed, from Tables 2 and 4 we can see that the ranking of mines according to the functional criterion largely corresponds to the ranking according to the generalized indicator. This means, ultimately, that the STSs of those mines, where more trucks are allocated to service the existing shovels, operate better. However, it is unknown what exactly should this ratio $\left(k_{N}^{\prime}=N_{t} / N_{S}\right)$ be so that the generalized indicator of the STS operation quality level is the highest, and it is not possible to determine it here, despite the fact that a large number of works have been devoted to the problem of determining the STS rational structure, for example [5, 10-15]. Obviously, it can be determined as a result of optimization of the STS operation quality indicators.

Out of the total number of leading mines, the Bachatsky mine, which occupies the 3rd place in the ranking list, stands out. For it, all the STS performance indicators have rather high values, and only one indicator - the haul distance $L_{h}$, and hence the haul time of trucks $t_{h}$ - is greatly overestimated, and this leads to a sharp decrease in the functional criterion with all the ensuing negative consequences. In the column for the Bachatsky mine in Table 4 , it can be seen that high values of some single indicators are adjacent to extremely low values of others, depending on the haul time of trucks, that is, their imbalance is evident. The same, but to a lesser extent, can be said about Kaltansky, Mokhovsky and even Krasnobrodsky mines.

The need to ensure an optimal balance of the STS operation quality indicators is confirmed by the fact that the indicators at mines with a higher functional criterion, as shown by the analysis, are more balanced. For example, the scatter of values of single indicators of the STS operation quality at the Taldinsky mine, which has the largest functional criterion $(\lambda=0,704)$, is $\pm 32,2 \%$, and at the Bachatsky mine, which occupies the 5 th place in the ranking list by the functional criterion, it is $\pm 53,7 \%$. This means that the optimal balance of the main indicators characterizing the STS operation also increases the level of its operation quality. Thus, there is one more confirmation of the need for an integrated (systemic) approach to the design of new STSs for open-pit mining.

\section{Conclusion}

The analysis of the quality level of the STS operation at open-pit coal mines allows to conclude that its increase can be achieved through the development of scientifically based methods for the optimal design of the STS, which make it possible to determine and optimally balance the main indicators characterizing them. The solution of these problems can be a powerful means of improving the operation quality of newly created shovel-truck systems for open-pit coal mining operations. 


\section{References}

1. Y. Voronov, Optimalnoe proektirovanie gornyh kariernyh mashin [Optimal design of open-pit mining machines] (Moscow, Innovative Engineering, 2015)

2. P. Zykov, Povyshenie tehnicheskogo urovnja kariernyh odnokovshovyh gidravlicheskih ekskavatorov na stadii proektirovanija [Increasing the technical level of openpit hydraulic excavators at the design stage] (Kemerovo, Kuzbass State Technical University, 2013)

3. A. Bujankin, Kompleksnaja otsenka i prognozirovanie pokazatelej kachestva ekspluatatsii kariernyh avtosamosvalov [Integrated assessment and prediction of indicators of mining truck operation quality] (Kemerovo, Kuzbass State Technical University, 2004)

4. S. Basmanov, Optimizatsija parametrov kariernyh avtosamosvalov dlja povyshenija ih tehnicheskogo urovnja [Optimization of parameters of mining trucks for increasing its technical level], Kemerovo, Kuzbass State Technical University (2012)

5. Y. Voronov, Ar. Voronov, E3S Web Conf. 21 (2017)

6. G. Solod, Osnovy kvalimetrii [The basics of qualimetry] Moscow, Moscow Mining Institute (1991)

7. Y. Voronov, A. Khoreshok, Ar. Voronov, N. Stenina, An. Voronov, Bulletin of the Kuzbass State Technical University. 3, 54 (2019)

8. Y. Voronov, An. Voronov, Ar. Voronov, E3S Web Conf. 105, 01048 (2019)

9. An. Voronov, A. Khoreshok, Y. Voronov, V. Zhdanov, Ar. Voronov, Mining Equipment and Electromechanics. 4, 3 (2019)

10. A. Krause, C. Musingwini, J. S. Afr. I. Min. Metall. 107, 469 (2007)

11. S. Ercelebi, A. Bascetin, J. S. Afr. I. Min. Metall. 109, 433 (2009)

12. M.A. May, Applications of queuing theory for open-pit truck-shovel haulage systems, Blacksburg, Virginia Polytechnic Institute and State University (2012)

13. C. Burt, L. Caccetta, Interfaces. 44(2), 143 (2014)

14. S. Dindarloo, M. Osanloo, S. Frimpong, J. S. Afr. I. Min. Metall. 115, 209-219 (2015)

15. Ar. Voronov, Optimizatsija pokazatelei ekspluatatsionnoi proizvoditelnosti ekskavatorno-avtomobilnyh kompleksov razrezov [Optimization of performance indicators of the shovel-truck systems at open-pit mines], Kemerovo, T.F. Gorbachev Kuzbass State Technical University, (2015) 